\title{
Regional Differences in the Response to Acute Blood Pressure Lowering After Cerebral Hemorrhage
}

Kazunori Toyoda, MD, PhD, Yuko Y. Palesch, PhD, Masatoshi Koga, MD, PhD, Lydia Foster, MS, Haruko Yamamoto, MD, PhD, Sohei Yoshimura, MD, PhD, Masafumi Ihara, MD, PhD, Mayumi Fukuda-Doi, MD, PhD, Shuhei Okazaki, MD, PhD, Kanta Tanaka, MD, Kaori Miwa, MD, PhD, Yasuhiro Hasegawa, MD, PhD, Yoshiaki Shiokawa, MD, PhD, Toru Iwama, MD, PhD, Kenji Kamiyama, MD, PhD, Haruhiko Hoshino, MD, PhD, Thorsten Steiner, MD, PhD, Byung-Woo Yoon, MD, PhD, Yongjun Wang, MD, PhD, Chung Y. Hsu, MD, PhD, and Adnan I. Qureshi, MD, PhD, for the ATACH-2 Trial Investigators

Neurolog ${ }^{\circledR}$ 2021;96:e740-e751. doi:10.1212/WNL.0000000000011229

\section{Abstract}

\section{Objective}

To compare the impact of intensive blood pressure (BP) lowering right after intracerebral hemorrhage $(\mathrm{ICH})$ on clinical and hematoma outcomes among patients from different geographic locations, we performed a prespecified subanalysis of a randomized, multinational, 2-group, open-label trial to determine the efficacy of rapidly lowering BP in hyperacute ICH (Antihypertensive Treatment of Acute Cerebral Hemorrhage [ATACH]-2), involving 537 patients from East Asia and 463 recruited outside of Asia.

\section{Methods}

Eligible patients were randomly assigned to a systolic BP target of 110 to $139 \mathrm{~mm} \mathrm{Hg}$ (intensive treatment) or 140 to $179 \mathrm{~mm} \mathrm{Hg}$ (standard treatment). Predefined outcomes were poor functional outcome (modified Rankin Scale score 4-6 at 90 days), death within 90 days, hematoma expansion at 24 hours, and cardiorenal adverse events within 7 days.

\section{Results}

Poor functional outcomes ( $32.0 \%$ vs $45.9 \%$ ), death (1.9\% vs $13.3 \%$ ), and cardiorenal adverse events (3.9\% vs $11.2 \%$ ) occurred significantly less frequently in patients from Asia than those outside of Asia. The treatment-by-cohort interaction was not significant for any outcomes. Only patients from Asia showed a lower incidence of hematoma expansion with intensive treatment (adjusted relative risk [RR] 0.56, 95\% confidence interval [CI] 0.38-0.83). Both Asian (RR 3.53, 95\% CI 1.28-9.64) and non-Asian (RR 1.71, 95\% CI 1.00-2.93) cohorts showed a higher incidence of cardiorenal adverse events with intensive treatment.

\section{Conclusions}

Poor functional outcomes and death 90 days after $\mathrm{ICH}$ were less common in patients from East Asia than those outside of Asia. Hematoma expansion, a potential predictor for poor clinical outcome, was attenuated by intensive BP lowering only in the Asian cohort.

\section{ClinicalTrials.gov Identifier}

NCT01176565.

\section{Classification of Evidence}

This study provides Class II evidence that, for patients from East Asia with ICH, intensive blood pressure lowering significantly reduces the risk of hematoma expansion.

\section{Correspondence}

Dr. Toyoda

toyoda@ncvc.go.jp

\section{MORE ONLINE}

\section{$\rightarrow$ Class of Evidence}

Criteria for rating therapeutic and diagnostic studies

NPub.org/coe

From the Department of Cerebrovascular Medicine (K. Toyoda, M.K., S.Y., K. Tanaka, K.M.), Center for Advancing Clinical and Translational Sciences (H.Y., M.F.-D., S.O.), and Department of Neurology (M.I.), National Cerebral and Cardiovascular Center, Suita, Japan; Department of Public Health Sciences (Y.Y.P., L.F.), Medical University of South Carolina, Charleston; Department of Neurology (Y.H.), St. Marianna University School of Medicine, Kawasaki; Department of Neurosurgery and Stroke Center (Y.S.), Kyorin University School of Medicine, Mitaka; Department of Neurosurgery (T.I.), Gifu University Graduate School of Medicine; Department of Neurosurgery (K.K.), Nakamura Memorial Hospital, Sapporo; Department of Neurology (H.H.), Tokyo Saiseikai Central Hospital, Japan; Department of Neurology (T.S.), Klinikum Frankfurt Höchst, Germany; Department of Neurology (B.-W.Y.), Seoul National University Hospital, South Korea; Beijing Tiantan Hospital (Y.W.), China; China Medical University (C.Y.H.), Taichung, Taiwan; and Zeenat Qureshi Stroke Research Center (A.I.Q.), University of Minnesota, Minneapolis.

Go to Neurology.org/N for full disclosures. Funding information and disclosures deemed relevant by the authors, if any, are provided at the end of the article. 


\section{Glossary}

ATACH = Antihypertensive Treatment of Acute Cerebral Hemorrhage; $\mathbf{B P}=$ blood pressure; $\mathbf{C I}=$ confidence interval; $\mathbf{I C H}=$ intracerebral hemorrhage; INTERACT2 = Second Intensive Blood Pressure Reduction in Acute Cerebral Haemorrhage Trial; $\mathrm{mRS}=$ modified Rankin Scale; NIHSS = NIH Stroke Scale; RR = relative risk; SAMURAI = Stroke Acute Management With Urgent Risk-Factor Assessment and Improvement; SBP = systolic BP.

Stroke was estimated to occur in $\approx 14$ million population annually and was the second largest cause of death $(\approx 5.5$ million) and the second most common cause of disabilityadjusted life-years $(\approx 116$ million) globally from 1990 through $2016{ }^{1}$ Of all strokes, $14 \%$ to $18.5 \%$ were reportedly intracerebral hemorrhages (ICHs). ${ }^{2,3}$ Although both the incidence and mortality of $\mathrm{ICH}$ decreased in the past 2 decades worldwide, ICH is still a devastating disease. ${ }^{1}$

Acute therapeutic strategies for ICH lag far behind those for acute ischemic stroke in their practical impact ${ }^{4,5}$; among these, acute lowering of elevated blood pressure (BP) may attenuate early hematoma expansion and have the potential to decrease death and disability. The Second Intensive Blood Pressure Reduction in Acute Cerebral Haemorrhage Trial (INTERACT2) demonstrated possibly better functional outcomes for patients with acute ICH with early intensive lowering to a targeted systolic BP (SBP) of $<140 \mathrm{~mm} \mathrm{Hg}$ than the standard target of SBP $<180 \mathrm{~mm} \mathrm{Hg}$ (odds ratio $0.87,95 \%$ confidence interval [CI] 0.75-1.01). ${ }^{6}$ However, another global randomized controlled trial, the Antihypertensive Treatment of Acute Cerebral Hemorrhage (ATACH)-2 trial, which overlapped in time with INTERACT2, did not show benefit in reducing the rate of the primary outcome of death or disability, defined as a modified Rankin Scale (mRS) score of 4 to 6 , between the 2 treatment groups with the same target level of SBP as in INTERACT2 (relative risk [RR] with intensive treatment $1.04,95 \%$ CI $0.85-1.27) .{ }^{7}$ We hypothesized that the prevalence and geographic variety of patients from Asia would have affected the difference in the efficacy outcomes between the trials.

\section{Methods}

\section{Classification of Evidence}

The primary research question was to evaluate the geographic differences in clinical outcomes and early hematoma expansion after ICH between patients from East Asia and those outside of Asia. This study provides Class II evidence that, for patients from East Asia with ICH, intensive BP lowering significantly reduces the risk of hematoma expansion.

\section{Standard Protocol Approvals, Registrations, and Patient Consents}

ATACH-2 was registered in ClinicalTrials.gov (NCT01176565) and the University Hospital Medical Information Network clinical trial registry in Japan (UMIN 000006526) and was approved by ethics committees/competent authorities in all participating sites. Informed consent was obtained from each participant, her/ his legally authorized representative, or a relative.

\section{Patients}

ATACH-2 was a randomized, multinational, 2-group, openlabel trial to determine the efficacy of rapidly lowering SBP in patients with hyperacute spontaneous supratentorial ICH from 110 sites in the United States, Japan, China, Taiwan, Germany, and South Korea. ${ }^{7-9}$ A detailed description of the protocol has been provided elsewhere. ${ }^{10}$ Briefly, patients with a Glasgow Coma Scale score $\geq 5$ and an SBP $\geq 180 \mathrm{~mm}$ $\mathrm{Hg}$ on arrival at the emergency department and intraparenchymal hematoma with a volume $<60 \mathrm{~cm}^{3}$ on initial non-contrast-enhanced $\mathrm{CT}$ were centrally randomized to undergo either intensive SBP lowering (target SBP $110-139 \mathrm{~mm} \mathrm{Hg}$ ) or standard SBP lowering (target SBP140-179 mm Hg) in a $1: 1$ ratio within 4.5 hours of symptom onset.

IV nicardipine infusion was started to reduce hourly minimum SBP to the target level within 2 hours of randomization and to maintain this level through 24 hours for each participant. SBP was measured every 5 minutes for the first 15 minutes after initiation of nicardipine infusion followed by at least every 15 minutes for the remainder of the first hour and at least every 30 minutes during the period from 1 to 24 hours. Minimum and maximum SBPs were recorded each hour.

Neurologic status was assessed with the NIH Stroke Scale (NIHSS) score at baseline by a qualified study investigator. The trial mandated a head CT at $24( \pm 8)$ hours after initiation of treatment. CT images underwent post hoc computerized volumetric analysis by central neuroimaging specialists who were blinded to the treatment assignment, clinical data, adverse events, and CT results from different time points. Postdischarge follow-up included telephone contact at 1 month to collect data on mRS scores, adverse events, and death and an in-person clinical evaluation at 90 days to perform physical and neurologic examinations and to assess the mRS score by a qualified investigator who did not participate in the randomization, treatment, or in-hospital clinical management of the study participants.

\section{Study Outcomes}

The outcome measures for the present exploratory analyses were (1) the proportion of patients with poor functional outcomes corresponding to an mRS score of 4 to 6 at 90 days; (2) death within 90 days; (3) hematoma expansion, defined as 
Table 1 Demographic and Clinical Characteristics of Patients by Cohort

\begin{tabular}{|c|c|c|c|c|c|c|c|}
\hline & \multirow[b]{2}{*}{$\begin{array}{l}\text { From Asia } \\
(n=537)\end{array}$} & \multirow{2}{*}{$\begin{array}{l}\text { Outside of } \\
\text { Asia } \\
(n=463)\end{array}$} & \multirow[b]{2}{*}{$p$ Value } & \multicolumn{2}{|l|}{ From Asia } & \multicolumn{2}{|l|}{ Outside of Asia } \\
\hline & & & & $\begin{array}{l}\text { Intensive } \\
(\mathrm{n}=264)\end{array}$ & $\begin{array}{l}\text { Standard } \\
(n=273)\end{array}$ & $\begin{array}{l}\text { Intensive } \\
(\mathrm{n}=236)\end{array}$ & $\begin{array}{l}\text { Standard } \\
(\mathrm{n}=227)\end{array}$ \\
\hline Women & $179(33.3)$ & $201(43.4)$ & 0.0011 & $95(36.0)$ & $84(30.8)$ & $101(42.8)$ & $100(44.1)$ \\
\hline Age, y & $61.2 \pm 13.0$ & $62.9 \pm 13.1$ & 0.0375 & $61.5 \pm 13.4$ & $60.9 \pm 12.6$ & $62.6 \pm 12.8$ & $63.2 \pm 13.4$ \\
\hline History of stroke/TIA, n (\%) & $66(12.3)$ & $98(21.4)$ & 0.0001 & $31(11.7)$ & 35 (12.9) & $49(21.1)$ & $49(21.7)$ \\
\hline Hypertension, $\mathrm{n}(\%)$ & $418(80.1)$ & $375(83.2)$ & 0.2175 & $214(82.6)$ & $204(77.6)$ & $197(86.4)$ & $178(79.8)$ \\
\hline Dyslipidemia, n (\%) & $98(19.2)$ & $143(33.3)$ & $<0.0001$ & $48(19.1)$ & $50(19.3)$ & $74(34.6)$ & $69(32.1)$ \\
\hline Diabetes mellitus, n (\%) & $73(13.7)$ & $113(24.7)$ & $<0.0001$ & $44(16.8)$ & $29(10.7)^{a}$ & $54(23.3)$ & $59(26.2)$ \\
\hline Current smoking, n (\%) & $175(32.6)$ & $89(19.2)$ & $<0.0001$ & $78(29.6)$ & $97(35.5)$ & $48(20.3)$ & $41(18.1)$ \\
\hline Glasgow Coma Scale score, n (\%) & & & 0.3898 & & & & \\
\hline $3-11$ & $84(15.6)$ & $63(13.6)$ & & $42(15.9)$ & $42(15.4)$ & $31(13.1)$ & $32(14.1)$ \\
\hline $12-14$ & $149(27.8)$ & $145(31.3)$ & & $71(26.9)$ & $78(28.6)$ & $81(34.3)$ & $64(28.2)$ \\
\hline 15 & $304(56.6)$ & $255(55.1)$ & & $151(57.2)$ & $153(56.0)$ & $124(52.5)$ & $131(57.7)$ \\
\hline NIHSS score, n (\%) & $10(6-15)$ & $12(6-17)$ & 0.0204 & $10(6-15)$ & $10(7-14.5)$ & $12(6-17)$ & $11(6-17)$ \\
\hline Baseline SBP, mm Hg & $199.9 \pm 24.5$ & $201.3 \pm 29.5$ & 0.4120 & $200.6 \pm 24.8$ & $199.3 \pm 24.3$ & $199.4 \pm 29.4$ & $203.3 \pm 29.6$ \\
\hline Hematoma volume, $\mathrm{mL}$ & $\begin{array}{l}10.1 \\
(5.4-18.1)\end{array}$ & $10.3(4.6-19.5)$ & 0.9928 & $9.8(5.3-17.6)$ & $\begin{array}{l}10.3 \\
(5.7-18.5)\end{array}$ & $10.8(4.6-19.6)$ & $\begin{array}{l}10.2 \\
(4.5-19.5)\end{array}$ \\
\hline Hematoma location, n (\%) & & & $<0.0001$ & & & & \\
\hline Basal ganglia & $300(56.4)$ & $178(45.1)$ & & $144(55.0)$ & $156(57.8)$ & $111(47.4)$ & $96(42.7)$ \\
\hline Thalamus & $195(36.6)$ & $207(38.8)$ & & $102(38.9)$ & $93(34.4)$ & $91(38.9)$ & $87(38.7)$ \\
\hline Lobe & $37(7.0)$ & $74(16.1)$ & & $16(6.1)$ & $21(7.8)$ & $32(13.7)$ & $42(18.7)$ \\
\hline $\begin{array}{l}\text { Intraventricular hemorrhage, } \mathrm{n} \\
(\%)\end{array}$ & $114(21.4)$ & $144(31.4)$ & 0.0004 & $46(17.6)$ & $68(25.2)^{a}$ & $75(32.1)$ & $69(30.7)$ \\
\hline Onset-to-randomization, $\min$ & $\begin{array}{l}170 \\
(125-220)\end{array}$ & $203(154-240)$ & $<0.0001$ & $\begin{array}{l}168.5 \\
(125-216)\end{array}$ & $\begin{array}{l}172 \\
(125-225)\end{array}$ & $\begin{array}{l}202 \\
(147.5-242)\end{array}$ & $\begin{array}{l}204 \\
(159-240)\end{array}$ \\
\hline
\end{tabular}

Abbreviations: NIHSS = NIH Stroke Scale; SBP = systolic blood pressure.

For categorical variables, numbers (percents) are presented with $\chi^{2} p$ value. For continuous variables, mean \pm SD (for normally distributed variables) or median (interquartile range) (for nonnormally distributed variables) values are presented with Wilcoxon rank $p$ values. Six patients are missing data for previous stroke/TIA, 27 for hypertension, 60 for dyslipidemia, 9 for diabetes mellitus, 5 for NIHSS score, 1 for baseline SBP, and 9 for items on CT (central reading): hematoma volume, hematoma location, and intraventricular hemorrhage.

a $p<0.05$ vs intensive.

an increase in volume $>6 \mathrm{~cm}^{3}$ on the 24-hour CT compared with the baseline $\mathrm{CT}^{11}$; and (4) renal and cardiac adverse events the grade 2 to 5 of the Common Terminology Criteria for Adverse Events version 4.03 (ctep.cancer.gov/protocoldevelopment/electronic_applications/ctc.htm; grade 1 [mild]-grade 5 [fatal]) within 7 days. All adverse events were judged by the investigators and recorded on the case report form on the study website. Independent reviews of all severe events were conducted by the physicians in the Independent Oversight Committee, blinded to clinical outcomes. Definitions of events were identical to the previous substudy of acute SBP levels achieved after $\mathrm{ICH}^{11}{ }^{11}$ Patients who underwent surgical procedures before the 24-hour CT were excluded from the analysis of hematoma expansion.

\section{Statistical Analysis}

A total of 1,000 patients were randomized in ATACH-2. All patients recruited in East Asia (Japan, China, Taiwan, and South Korea) were included in the Asian group, and all patients recruited outside of Asia (United States and Germany) were included in the non-Asian group, regardless of Asian or non-Asian race. Analysis of each outcome was performed under the intention-to-treat principle, including all patients randomized to either treatment group. In addition, a secondary analysis on racial differences was performed with 980 patients who self-identified as White, Black, or Asian race in accordance with the $\mathrm{NIH}$ guidelines for reporting race (grants.nih.gov/grants/guide/notice-files/NOT-OD-01-053. html). 


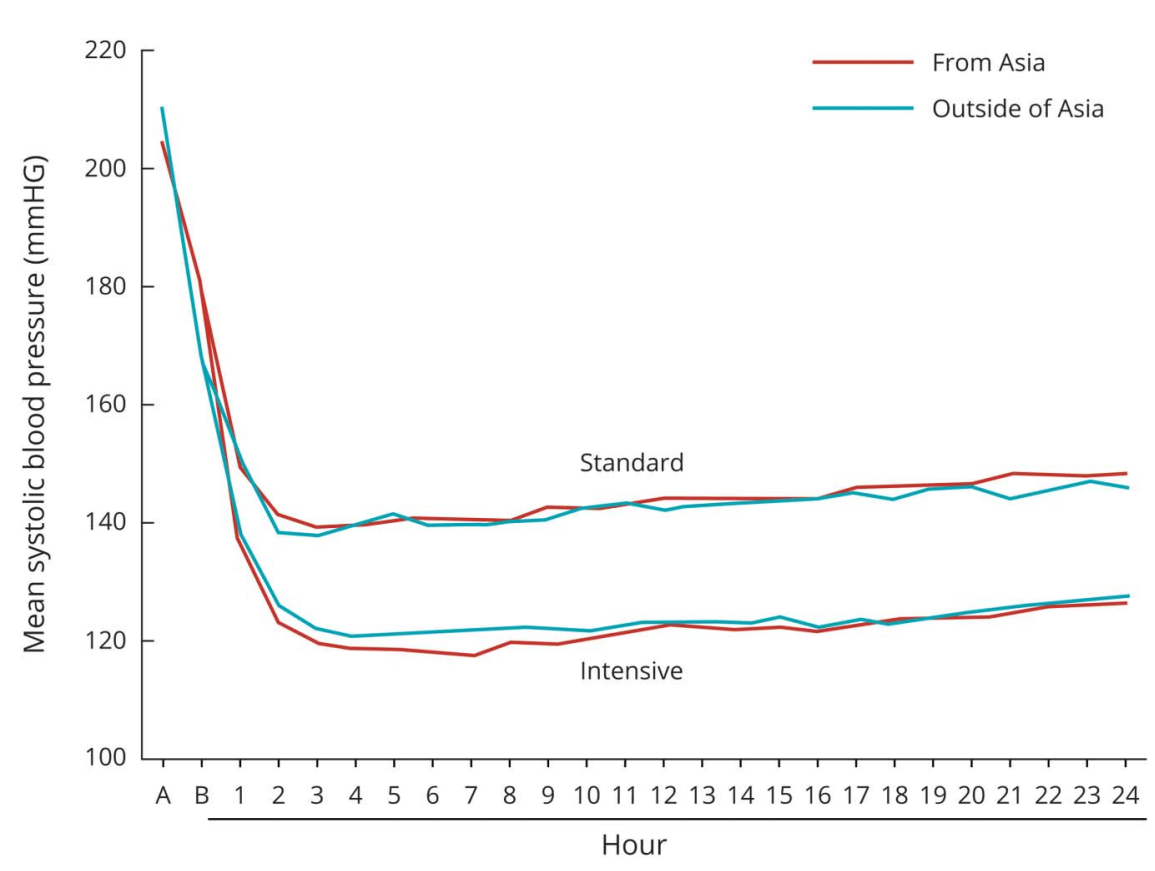

Demographic and baseline clinical characteristics and outcomes were compared between patients from Asia and those outside of Asia (or among Asian, White, and Black participants) using $\chi^{2}$ tests for categorical variables and Wilcoxon rank tests for continuous variables. Interaction effects between treatment and cohort were assessed using the cohort, treatment group, and the treatment-by-cohort interaction term as covariates and further adjusted for known predictors for clinical outcomes after $\mathrm{ICH}$ that were chosen in our previous substudy of ATACH- $2,{ }^{8}$ including sex, age, baseline NIHSS score, baseline hematoma volume, hematoma location (lobar hematoma), intraventricular hemorrhage, and time from symptom onset to randomization. Quartile categories were used for these continuous factors.

The PROC GENMOD procedure of the latest version of SAS software and JMP version 14 software (SAS Institute, Cary, NC) were used to obtain test statistics and results. Values of $p<0.15$ were considered significant for assessment of the treatment-by-cohort interaction. In the other comparisons, values of $p<0.05$ were considered significant because the analyses were exploratory rather than an attempt to definitively establish the existence of racial differences in the effect of intensive SBP reduction after ICH. Therefore, caution in interpretation of any significant findings is advised.

\section{Data Availability}

The whole dataset of ATACH-2 is currently open to the public and is available on request to the National Institute of Neurologic Disorders and Stroke.

\section{Results}

\section{Comparison Between Patients Recruited in and Outside of Asia}

Of a total of 1,000 patients studied (mean \pm SD age, $62.0 \pm 13.1$ years, 380 women), 537 were recruited from Asia (288 from Japan, 137 from China, 95 from Taiwan, and 17 from South Korea), and all were of Asian race. The remaining 463 were recruited in the United States (422) and Germany (41), with 62\% (287) White, 28\% (131) Black, 5\% (25) Asian, and 4\% (20) other races. Table 1 shows the demographic and clinical characteristics compared between the patients from Asian and non-Asian regions. Of clinical significance were higher proportions of risk factors in the non-Asian cohort (history of stroke or TIA, dyslipidemia, diabetes mellitus, lobar hematoma, and intraventricular hemorrhage), but current smoking was more common in the Asian cohort. Onset-to-randomization time was 33 minutes longer in the non-Asian cohort.

On average, the Asian and non-Asian cohorts had similar profiles of SBP levels during the initial 24 hours after randomization (figure 1). The average mean hourly minimum SBPs during 24 hours were nearly identical (132.8 $\pm 13.9 \mathrm{~mm} \mathrm{Hg}$ in Asian and $133.0 \pm 13.5 \mathrm{~mm} \mathrm{Hg}$ in non-Asian participants).

Figure 2 shows mRS scores at 90 days. The proportion of poor functional outcomes corresponding to an $\mathrm{mRS}$ score of 4 to 6 was $32.0 \%$ (170 of 532) in the Asian cohort and $45.9 \%$ (197 of 429) in the non-Asian cohort $(p<0.0001)$. Mortality, corresponding to an mRS score of 6 , was $1.9 \%$ (10 of 532) in Asian and $13.3 \%$ (57 of 429$)$ in non-Asian participants $(p<$ 


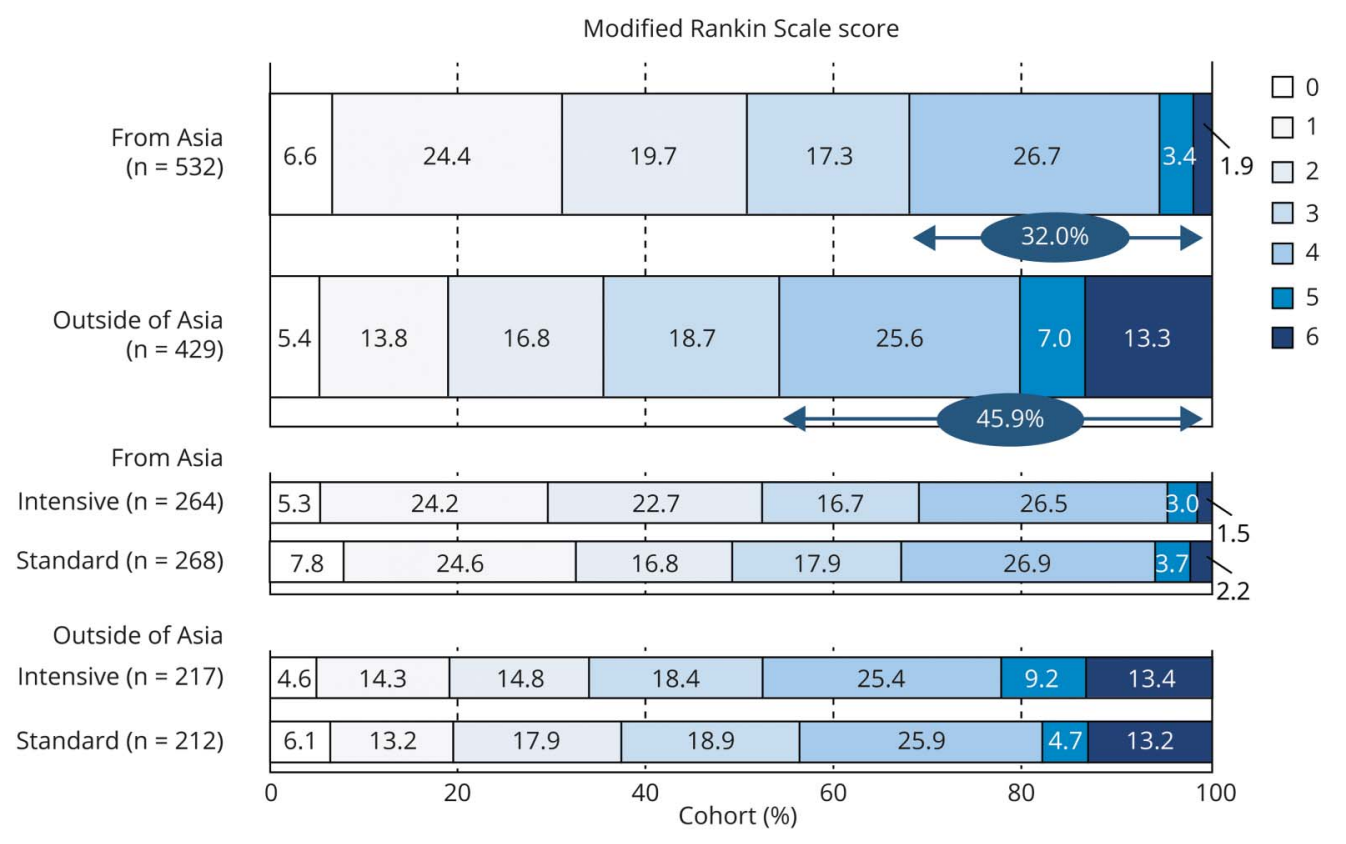

0.0001). After multivariable adjustment, the rates of both poor functional outcome (RR 0.86, 95\% CI 0.74-0.99) and mortality (RR 0.19, 95\% CI 0.10-0.38) were lower in Asian participants. There was no significant treatment-by-cohort interaction of poor functional outcome $(p=0.821)$ or death $(p=0.557$, figure 3$)$, although Asian participants showed relatively lower risk for death (RR 0.66) than non-Asian participants (RR 1.01) by intensive SBP lowering.

Early hematoma expansion was not assessed for 71 patients; baseline CT data were not available in 9; follow-up CT data were not available in 15; and follow-up CT data were affected by emergent surgery in 47 . A total of 170 of the remaining 929 patients (18.3\%) showed hematoma expansion. Overall, hematoma expansion was identified in $17.2 \%$ ( 88 of 513) of patients from Asia and 19.7\% (82 of 416) of those outside of Asia ( $p=$ 0.3168 ). There was no significant treatment-by-cohort interaction of expansion ( $p=0.226$, figure 3 ), while hematoma expansion was less common in the intensive treatment group than in the standard treatment group after multivariable adjustment only in Asian participants (RR 0.56, 95\% CI 0.38-0.83).

Cardiorenal adverse events (moderate, severe, life-threatening, or fatal) within 7 days were identified in 3.9\% (21 of 537) of patients from Asia and 11.2\% (52 of 463) of those outside of Asia $(p<0.0001)$. After multivariable adjustment, the rate of adverse events (RR 0.45, 95\% CI 0.27-0.75) was lower in Asian participants. Details of the adverse events are documented in table 2. There was no significant treatment-by-cohort interaction of expansion ( $p=0.187$, figure 3$)$; the rate of patients with adverse events was higher in the intensive treatment group than in the standard treatment group in both Asian (RR 3.53,
95\% CI 1.29-9.64) and non-Asian participants (RR 1.71, 95\% CI 1.00-2.93) after multivariable adjustment.

\section{Comparison Among Self-Identified Racial Categories (Asian, White, and Black Participants)}

Table 3 shows demographic and clinical characteristics of patients among Asian (562 patients), White (287), and Black (131) participants. Unique characteristics of Black especially compared to White participants included lower mean age, higher frequency of hypertension, and higher level of baseline SBP. The 3 groups had similar profiles of mean hourly minimum SBP during the initial 24 hours after randomization, with average SBP of $131.8 \pm 13.5 \mathrm{~mm} \mathrm{Hg}$ in White participants and $135.1 \pm$ $13.6 \mathrm{~mm} \mathrm{Hg}$ in Black participants ( $p=0.0502$ among 3 races).

Poor functional outcome was identified in $45.8 \%$ of White and $44.5 \%$ of Black participants $(p<0.0001$ among 3 races [the same applies to the following], figure 2); mortality in $16.0 \%$ and $7.7 \%$, respectively $(p<0.0001)$; hematoma expansion in $20.9 \%$ and $16.4 \%$, respectively $(p=0.3918)$; and cardiorenal adverse events in $11.9 \%$ and $8.4 \%$, respectively $(p=0.0003)$. After multivariable adjustment, the rate of poor functional outcome (RR 0.89, 95\% CI 0.76-1.04 vs White participants; and RR $0.81,95 \%$ CI $0.65-1.01$ vs Black participants) tended to be lower and mortality (RR 0.18, 95\% CI 0.09-0.33; and RR 0.27, 95\% CI 0.11-0.65, respectively) was lower in Asian participants than the other 2 races. Cardiorenal adverse events were lower in Asian than White (RR 0.48, 95\% CI 0.29-0.80) participants.

The treatment-by-cohort interaction was not significant for any outcomes (table 4). Hematoma expansion was less common 
Figure 3 Forest Plot for Outcomes Comparing Asian and Non-Asian Cohorts

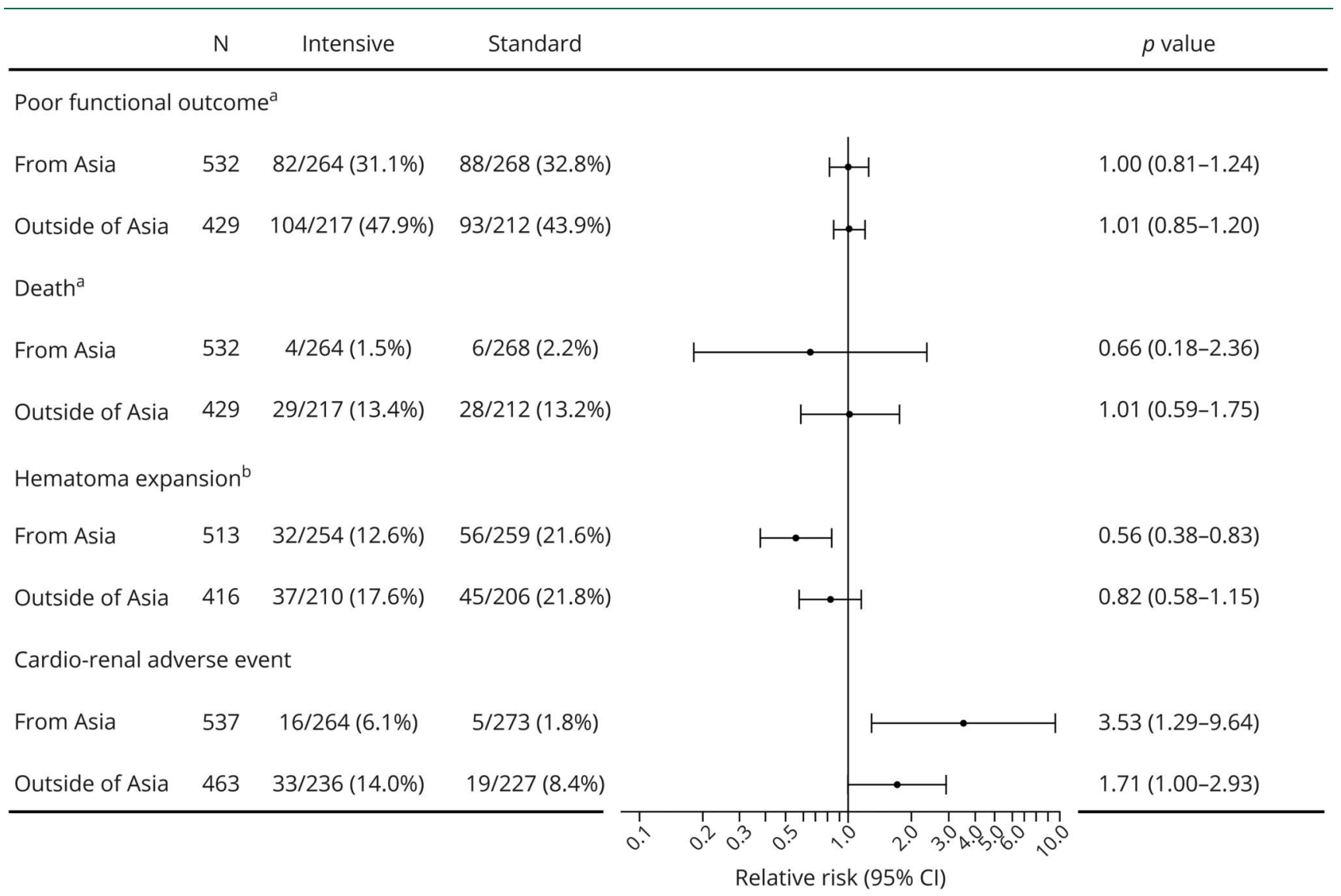

Adjusted by sex, age (quartile), baseline NIH Stroke Scale score (quartile), hematoma volume (quartile), lobar hematoma, and onset-to-randomization time

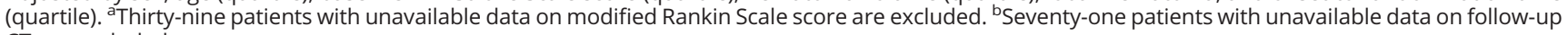
CT are excluded.

(RR 0.57, 95\% CI 0.39-0.83) and cardiorenal adverse events were more common ( $R R 2.75$, 95\% CI 1.15-6.56) in the intensive treatment group than in the standard treatment group after multivariable adjustment only in Asian participants.

\section{Discussion}

In the present analysis of patients from Asia and outside of Asia of the ATACH-2 trial data, the aim was to determine the association between geographic locations and clinical (90-day $\mathrm{mRS}$ score), imaging (hematoma expansion within 24 hours), and safety (cardiorenal adverse events within 7 days) outcomes in patients with acute ICH. One of the major findings was the large differences in $\mathrm{ICH}$ characteristics between the patients from Asian (to be precise, East Asian) and non-Asian regions. In particular, hematomas in the basal ganglia were more common and intraventricular hemorrhage was less common in the Asian cohort than in the non-Asian cohort. Second, the Asian cohort overall had better outcomes in terms of lower rates of poor functional outcome (32.0\% vs $45.9 \%$, absolute difference 13.9 percentage points) and death (1.9\% vs $13.3 \%$, absolute difference 11.4 percentage points) and lower incidence of cardiorenal adverse events (3.9\% vs $11.2 \%$, absolute difference 7.3 percentage points) than the non-Asian cohort. Third, intensive SBP lowering did not show significant treatment-by-cohort interactions on clinical outcomes, hematoma expansion, and cardiorenal adverse events, although the direction of the effect of intensive SBP-lowering treatment was positive in the Asian cohort with respect to death. Fourth, hematoma expansion was significantly attenuated by intensive SBP lowering only in the Asian cohort. Fifth, cardiorenal adverse events were significantly increased by intensive SBP lowering in both Asian and non-Asian cohorts. These results were similar when the 3 races by selfidentification, Asian, White, and Black, were compared.

A reason for the neutral results of the ATACH-2 trial was that intensive SBP lowering did not sufficiently reduce hematoma expansion, partly because the majority of participants had relatively mild ICH, with a Glasgow Coma Scale score of 15 and median hematoma volume of $10 \mathrm{~mL}^{7}$ A meta-analysis of 5 randomized controlled trials, including INTERACT2 and ATACH-2, with a total of 4,360 patients reported that intensive BP lowering was associated with a nonsignificant trend for a lower risk of death or disability at 3 months and for a lower risk of hematoma expansion. ${ }^{12}$ A pooled analyses of INTERACT2 and ATACH-2 indicated a continuous 
Table 2 Cardiorenal Adverse Events Within 7 Days

\begin{tabular}{|c|c|c|c|c|}
\hline & $\begin{array}{l}\text { From Asia, Intensive } \\
\text { Treatment, } n\end{array}$ & $\begin{array}{l}\text { From Asia, Standard } \\
\text { Treatment, } n\end{array}$ & $\begin{array}{l}\text { Outside of Asia, Intensive } \\
\text { Treatment, } n\end{array}$ & $\begin{array}{l}\text { Outside of Asia, Standard } \\
\text { Treatment, } n\end{array}$ \\
\hline Renal failure & 7 & 0 & 6 & 3 \\
\hline Urinary retention & 0 & 1 & 0 & 1 \\
\hline Increased creatinine level & 0 & 0 & 1 & 0 \\
\hline $\begin{array}{l}\text { Other renal adverse } \\
\text { events }\end{array}$ & 0 & 0 & 4 & 1 \\
\hline Atrial fibrillation & 2 & 0 & 2 & 2 \\
\hline Hypotension & 0 & 0 & 4 & 2 \\
\hline Hypertension & 0 & 0 & 2 & 2 \\
\hline Tachycardia & 1 & 1 & 1 & 1 \\
\hline Bradycardia & 0 & 0 & 1 & 1 \\
\hline $\begin{array}{l}\text { Supraventricular } \\
\text { tachycardia }\end{array}$ & 0 & 0 & 1 & 0 \\
\hline Ventricular extrasystoles & 0 & 0 & 0 & 1 \\
\hline Cardiac arrest & 0 & 1 & 0 & 2 \\
\hline Cardiac failure & 3 & 1 & 0 & 0 \\
\hline Cardiac collapse & 1 & 0 & 1 & 0 \\
\hline Myocardial infarction & 0 & 0 & 1 & 1 \\
\hline Chest pain & 0 & 0 & 2 & 0 \\
\hline Increased troponin level & 0 & 0 & 1 & 1 \\
\hline $\begin{array}{l}\text { Other cardiovascular } \\
\text { adverse events }\end{array}$ & 2 & 1 & 5 & 0 \\
\hline Total & 16 & 5 & 32 & 18 \\
\hline
\end{tabular}

Events with grade 2 to 5 of the Common Terminology Criteria for Adverse Events version 4.03 are listed. Most severe events in each patient are assessed.

association between the level of achieved SBP in the initial 24 hours and the distribution of $\mathrm{mRS}$ scores at 90 days. ${ }^{13}$ There were several differences in study protocols such as time allowed from symptom onset to randomization and allowable antihypertensive drug, and in therapeutic results, including the target SBP levels and the time frame to achieve those levels, between INTERACT2 and ATACH-2. ${ }^{6,7}$ In addition, there was a difference in the regional distribution of participants; $68 \%$ were from China in INTERACT2 and 56\% were from 4 countries of East Asia in ATACH-2.

The predominance of intracranial arteriopathy and arteriolopathy is a unique feature of stroke in Asia. ${ }^{14}$ As a good example, ICH is 2 to 4 times more common in Asian than in White individuals. ${ }^{15,16}$ Hereditary susceptibility to intracranial vasculopathy, ${ }^{14}$ high sodium intake, ${ }^{17}$ high sensitivity to warfarin, ${ }^{18}$ and other factors cause a high incidence of ICH in Asian individuals. Asian participants had smaller hematoma size at baseline and were less likely to die and had better quality of life than White participants according to the Virtual International Stroke Trials Archive and Efficacy of Nitric Oxide in Stroke Trial involving 1,011 patients. ${ }^{19}$
Another meta-analysis reported lower mortality after ICH in Japan than other countries, ${ }^{16}$ presumably due in part to the tendency of maintaining intensive therapy even for terminal patients.

The ATACH-2 trial data present a valuable opportunity to assess baseline characteristics and outcomes of patients with ICH from Asia compared to those outside of Asia because the trial involved 1,000 participants with nearly equal proportions of Asian and non-Asian cohorts. In an analysis limited to patients receiving standard SBP-lowering treatment, poor functional outcome at 90 days was less common $(32.8 \%$ vs $43.9 \%)$, as was death (2.2\% vs $13.2 \%)$, in Asian than nonAsian participants, although the initial NIHSS score and hematoma volume were almost identical. Thus, patients from Asia seem to recover relatively better from ICH than those outside of Asia with the same patient selection criteria for patients independently of intensive SBP lowering.

Hematoma expansion during the initial hours is an established risk factor for poor outcome after $\mathrm{ICH}^{20,21}$ In the ATACH-2 cohort, hematoma expansion was significantly associated with 
Table 3 Demographic and Clinical Characteristics of Patients by Self-Identified Racial Categories

\begin{tabular}{|c|c|c|c|c|}
\hline & Asian Participants $(n=562)$ & White Participants $(n=287)$ & Black Participants $(n=131)$ & $p$ Value \\
\hline Women, n (\%) & $189(33.6)$ & $130(45.3)$ & $56(42.7)$ & 0.002 \\
\hline Age, y & $61.0 \pm 13.1$ & $65.6 \pm 13.5$ & $57.6 \pm 10.3$ & $<0.001$ \\
\hline History of stroke/TIA, n (\%) & $70(12.5)$ & $57(20.1)$ & $32(24.6)$ & $<0.001$ \\
\hline Hypertension, $\mathrm{n}(\%)$ & 439 (80.4) & $219(78.8)$ & $119(92.2)$ & 0.003 \\
\hline Dyslipidemia, n (\%) & $106(19.8)$ & $95(35.6)$ & $35(29.7)$ & $<0.001$ \\
\hline Diabetes mellitus, $\mathbf{n}(\%)$ & $80(14.4)$ & $62(22.1)$ & $39(30.5)$ & $<0.001$ \\
\hline Current smoking, n (\%) & 179 (31.9) & $42(14.6)$ & $34(26.0)$ & $<0.001$ \\
\hline Glasgow Coma Scale score, n (\%) & & & & 0.082 \\
\hline $3-11$ & $89(15.8)$ & $41(14.3)$ & $10(7.6)$ & \\
\hline $12-14$ & $154(27.4)$ & $94(32.8)$ & $44(33.6)$ & \\
\hline 15 & $319(56.8)$ & $152(53.0)$ & $77(58.8)$ & \\
\hline NIHSS score & $10(6-15)$ & $12(6.5-17)$ & $11(6-18)$ & 0.1426 \\
\hline Baseline SBP, mm Hg & $199.7 \pm 24.5$ & $199.7 \pm 29.4$ & $206.6 \pm 30.6$ & 0.0262 \\
\hline Hematoma volume, $\mathrm{mL}$ & $10.1(5.4-18.1)$ & $10.4(5.0-19.6)$ & $9.6(4.1-18.4)$ & 0.6901 \\
\hline Hematoma location, $\mathrm{n}(\%)$ & & & & $<0.0001$ \\
\hline Basal ganglia & $310(55.7)$ & $126(44.2)$ & $63(48.8)$ & \\
\hline Thalamus & $208(37.3)$ & $112(39.3)$ & $45(34.9)$ & \\
\hline Lobe & $39(7.0)$ & $47(16.5)$ & $21(16.3)$ & \\
\hline Intraventricular hemorrhage, $\mathrm{n}(\%)$ & $122(21.9)$ & $89(31.2)$ & $42(32.6)$ & 0.0028 \\
\hline Onset-to-randomization, $\min$ & $170.5(128-221)$ & $201(146-240)$ & $204(159-265)$ & $<0.0001$ \\
\hline
\end{tabular}

Abbreviations: NIHSS = NIH Stroke Scale; SBP = systolic blood pressure.

For categorical variables, numbers (percent) are presented with $\chi^{2} p$ value. For continuous variables, mean $\pm S D$ (for normally distributed variables) or median (interquartile range) (for nonnormally distributed variables) values are presented with Wilcoxon rank $p$ values.

poor functional outcome; $65.9 \%$ with expansion and $29.5 \%$ without expansion had poor outcomes. The possibly positive effect in INTERACT2 and the neutral effect in ATACH-2 on good clinical outcomes by intensive SBP lowering are due in part to weak protection against hematoma expansion by intensive treatment. ${ }^{6,7}$ In contrast, hematoma expansion was attenuated by intensive treatment in the Asian cohort of ATACH-2, showing a decrease in expansion by $9 \%$ absolutely and by $48 \%$ relative to patients receiving standard SBP lowering, although the treatment-by-cohort interaction was not significant. Black participants also showed an absolute decrease in expansion by $8 \%$ after intensive treatment, without a statistically significant difference presumably due to the small number of patients.

Median onset-to-randomization time was 33.5 minutes shorter in the Asian cohort than non-Asian cohort. A shorter time delay appears to be essential for acute $\mathrm{ICH}$ therapy. The rate of hematoma expansion is the highest in the initial 3 hours after symptom onset. ${ }^{11,20,22}$ The initial inclusion criterion of ATACH2 was not within 4.5 hours but within 3 hours of symptom onset ${ }^{10}$; $56.6 \%$ of Asian and $39.0 \%$ of non-Asian participants met the older criterion. Time from randomization (or imaging) to reach the target SBP level was inversely associated with hematoma expansion in INTERACT2 and our multicenter, observational, Stroke Acute Management With Urgent Risk-Factor Assessment and Improvement (SAMURAI)-ICH study. ${ }^{23,24}$ In addition, another exploratory analysis of the ATACH-2 reported that intensive SBP lowering was associated with a decreased risk for expansion of basal ganglionic hematoma but not of thalamic hematoma or lobar hematoma. ${ }^{25} \mathrm{ICH}$ at the basal ganglia has mostly a hypertensive etiology. Severe hypertensive vasculopathy would predispose a patient to additional rupture of small vessels triggered by a BP surge, and intensive SBP lowering would prevent them from rupture and attenuate hematoma expansion. Patients from Asia had 10\% more ICHs in the basal ganglia and may have received a clearer protective effect from hematoma expansion than non-Asian patients.

Cardiorenal adverse events were significantly associated with poor functional outcome in the ATACH-2 trial cohort ${ }^{8}$; $62.5 \%$ with events and $36.2 \%$ without events had poor 
Table 4 Comparison of Outcomes Among 3 Self-Identified Racial Categories

\begin{tabular}{|c|c|c|c|c|c|}
\hline & No. & Intensive, $\%$ & Standard, \% & RR $(95 \% \mathrm{Cl})$ & $p$ for Interaction (vs Asian) \\
\hline \multicolumn{6}{|c|}{ Poor functional outcome ${ }^{a}$} \\
\hline Asian participants & 555 & 31.3 & 33.9 & $1.00(0.81-1.22)$ & - \\
\hline White participants & 269 & 47.8 & 43.7 & $1.02(0.81-1.27)$ & 0.946 \\
\hline Black participants & 117 & 48.4 & 39.6 & $1.11(0.76-1.62)$ & 0.566 \\
\hline \multicolumn{6}{|l|}{ Death $^{a}$} \\
\hline Asian participants & 555 & 1.5 & 2.5 & $0.59(0.17-2.03)$ & - \\
\hline White participants & 269 & 14.9 & 17.0 & $0.92(0.49-1.75)$ & 0.581 \\
\hline Black participants & 117 & 9.4 & 5.7 & $1.32(0.29-6.07)$ & 0.503 \\
\hline \multicolumn{6}{|l|}{ Hematoma expansion $^{b}$} \\
\hline Asian participants & 537 & 12.8 & 21.8 & $0.57(0.39-0.83)$ & - \\
\hline White participants & 258 & 19.7 & 22.1 & $0.97(0.63-1.49)$ & 0.097 \\
\hline Black participants & 117 & 12.5 & 20.8 & $0.52(0.23-1.16)$ & 0.684 \\
\hline \multicolumn{6}{|c|}{ Cardiorenal adverse event } \\
\hline Asian participants & 562 & 6.5 & 2.5 & $2.75(1.15-6.56)$ & - \\
\hline White participants & 287 & 14.8 & 9.0 & $1.57(0.82-3.01)$ & 0.280 \\
\hline Black participants & 131 & 12.3 & 3.5 & $3.49(0.96-12.8)$ & 0.907 \\
\hline
\end{tabular}

Abbreviations: $\mathrm{Cl}$ = confidence interval; $\mathrm{RR}=$ relative risk.

Adjusted by sex, age (quartile), baseline NIH Stroke Scale score (quartile), hematoma volume (quartile), lobar hematoma, intraventricular hemorrhage, and onset-to-randomization time (quartile).

a Thirty-nine patients with unavailable data on modified Rankin Scale score are excluded.

${ }^{\text {b }}$ Sixty-eight patients with unavailable data on follow-up CT are excluded.

outcomes $(p<0.0001)$. The observed excess cardiorenal adverse events in intensive SBP lowering for patients with acute ICH were more common in both the Asian and nonAsian cohorts. Intensive SBP lowering is known to cause acute kidney injury in patients with acute $\mathrm{ICH}^{26}$ Thus, any beneficial effects of intensive SBP lowering on clinical outcomes by suppressing hematoma expansion may be offset by the adverse events. In addition, cardiorenal adverse events were much more common in the non-Asian than Asian cohort.

Although the patients recruited from 4 East Asian countries were regarded as the Asian cohort in the present study, Asia includes $>4$ dozen countries and an extremely wide variety of physical phenotypes, socioeconomic political boundaries, and cultural practices. Thus, the present results would not be generalizable to persons under the broad social category of Asian. Similarly, patients recruited only in United States and Germany were not representative of all non-Asian people. Inclusion of 25 patients from United States or Germany of Asian ancestry would strengthen or weaken the difference in the results between the Asian and non-Asian cohorts. A wide variety of factors other than differences in ancestry might underlie regional differences in $\mathrm{ICH}$ presentations, outcomes, and responses to interventions. These problems were essential limitations of the present study.
In addition, the following limitations to the present study need to be considered. First, patients with ICH with more severe symptoms were excluded, including those with huge hematoma and those with infratentorial hemorrhage. In fact, the patient sample in the study was dominated by cases of milder $\mathrm{ICH}$, with $56 \%$ having a Glasgow Coma Scale score of 15 and median hematoma volume of $10 \mathrm{~mL}$. Second, the numbers of patients in some subgroups, especially the Black group, were small, which might weaken statistical power. Third, data on premorbid $\mathrm{mRS}$ scores, which might influence mRS scores at 90 days, were not collected. Fourth, cardiorenal adverse events were reported by the nonblinded investigators, although severe events were checked by blinded physicians in the Independent Oversight Committee.

Patients from East Asia seemed to recover relatively better from $\mathrm{ICH}$ than those outside of Asia with the same patient selection criteria. Intensive SBP-lowering treatment showed a protective effect against hematoma growth in the Asian cohort, although the treatment did not improve the clinical outcomes at 3 months.

\section{Study Funding}

Supported by grants from the National Institute of Neurologic Disorders and Stroke (U01-NS061861 and U01-NS059041 to Dr. Palesch and U01-NS062091 to Dr. Qureshi), by a grant from 
the Japan Society for the Promotion of Science (KAKENHI 17H04308 to Dr. Toyoda), and by a grant from the Japan Agency for Medical Research and Development (AMED 20lk0201094h0002 and 20lk0201109h0001 to Dr. Toyoda).

\section{Disclosure}

Dr. Toyoda reports honoraria from Daiichi-Sankyo, Bayer Yakuhin, Brystol-Meyers-Squibb (BMS), and Nippon Behringer Ingerheim. Dr. Koga reports honoraria from Bayer Yakuhin, BMS/Pfizer, Otsuka, Daiichi-Sankyo, Nippon Boehringer Ingelheim, and Takeda; scientific advisory board from Ono; and research support from Takeda, DaiichiSankyo, Nippon Boehringer Ingelheim, Astellas, Pfizer, and Shionogi. Dr. Ihara reports grants from Otsuka Pharmaceutical Ltd, BMS, and Shimadzu Corp. Dr. Hasegawa reports honoraria from Nippon Behringer Ingerheim. None of the other authors have any conflicts of interest to declare. Go to Neurology.org/ $\mathrm{N}$ for full disclosures.

\section{Publication History}

Received by Neurology April 13, 2020. Accepted in final form September 25, 2020.

\section{Appendix 1 Authors}

\begin{tabular}{lll}
\hline Name & Location & Contribution \\
\hline $\begin{array}{l}\text { Kazunori } \\
\text { Toyoda, } \\
\text { MD, PhD }\end{array}$ & $\begin{array}{l}\text { National Cerebral and } \\
\text { Cardiovascular Center, } \\
\text { Suita, Japan }\end{array}$ & $\begin{array}{l}\text { Execution of ATACH2, design } \\
\text { of the present substudy, wrote } \\
\text { the first draft of the } \\
\text { manuscript, statistical } \\
\text { analysis, and provided tables, } \\
\text { figures, and references }\end{array}$ \\
\hline $\begin{array}{l}\text { Yuko Y. } \\
\text { Palesch, } \\
\text { PhD }\end{array}$ & Medical University of & $\begin{array}{l}\text { Execution of ATACH2, } \\
\text { conception and design of } \\
\text { ATACH2, design of the present } \\
\text { substudy, statistical analysis }\end{array}$ \\
\hline $\begin{array}{l}\text { Masatoshi } \\
\text { Koga, MD, } \\
\text { PhD }\end{array}$ & Natina, Charleston & Cardional Cerebral and \\
Suita, Japan & $\begin{array}{l}\text { Execution of ATACH2 (major } \\
\text { role in the acquisition of data), } \\
\text { design of the present } \\
\text { substudy, revised the } \\
\text { manuscript for intellectual } \\
\text { content }\end{array}$
\end{tabular}

\begin{tabular}{lll}
\hline Lydia & Medical University of & Execution of ATACH2, \\
Foster, MS & South & $\begin{array}{l}\text { statistical analysis, revised the } \\
\text { manuscript for intellectual } \\
\text { Carolina, Charleston } \\
\text { content }\end{array}$
\end{tabular}

\begin{tabular}{lll}
\hline $\begin{array}{l}\text { Haruko } \\
\text { Yamamoto, } \\
\text { MD, PhD }\end{array}$ & $\begin{array}{l}\text { National Cerebral and } \\
\text { Cardiovascular Center, } \\
\text { Suita, Japan }\end{array}$ & $\begin{array}{l}\text { Execution of ATACH2, design } \\
\text { of the present substudy, } \\
\text { revised the manuscript for } \\
\text { intellectual content }\end{array}$ \\
\hline $\begin{array}{l}\text { Sohei } \\
\text { Yoshimura, } \\
\text { MD, PhD }\end{array}$ & $\begin{array}{l}\text { National Cerebral and } \\
\text { Cardiovascular Center, }\end{array}$ & $\begin{array}{l}\text { Execution of ATACH2, revised } \\
\text { the manuscript for intellectual } \\
\text { content }\end{array}$ \\
\hline $\begin{array}{l}\text { Masafumi } \\
\text { Ihara, MD, }\end{array}$ & $\begin{array}{l}\text { National Cerebral and } \\
\text { PhD }\end{array}$ & $\begin{array}{l}\text { Execution of ATACH2, revised } \\
\text { the manuscript for intellectual } \\
\text { content }\end{array}$ \\
\hline $\begin{array}{l}\text { Mayumi Japan } \\
\text { Fukuda-Doi, } \\
\text { MD, PhD }\end{array}$ & $\begin{array}{l}\text { National Cerebral and } \\
\text { Cardiovascular Center, }\end{array}$ & $\begin{array}{l}\text { Execution of ATACH2, revised } \\
\text { the manuscript for intellectual } \\
\text { content }\end{array}$ \\
\hline
\end{tabular}

Appendix 1 (continued)

\begin{tabular}{|c|c|c|}
\hline Name & Location & Contribution \\
\hline $\begin{array}{l}\text { Shuhei } \\
\text { Okazaki, } \\
\text { MD, PhD }\end{array}$ & $\begin{array}{l}\text { National Cerebral and } \\
\text { Cardiovascular Center, } \\
\text { Suita, Japan }\end{array}$ & $\begin{array}{l}\text { Execution of ATACH2, revised } \\
\text { the manuscript for intellectual } \\
\text { content }\end{array}$ \\
\hline $\begin{array}{l}\text { Kanta } \\
\text { Tanaka, MD }\end{array}$ & $\begin{array}{l}\text { National Cerebral and } \\
\text { Cardiovascular Center, } \\
\text { Suita, Japan }\end{array}$ & $\begin{array}{l}\text { Execution of ATACH2, revised } \\
\text { the manuscript for intellectual } \\
\text { content }\end{array}$ \\
\hline $\begin{array}{l}\text { Kaori Miwa, } \\
\text { MD, PhD }\end{array}$ & $\begin{array}{l}\text { National Cerebral and } \\
\text { Cardiovascular Center, } \\
\text { Suita, Japan }\end{array}$ & $\begin{array}{l}\text { Execution of ATACH2, revised } \\
\text { the manuscript for intellectual } \\
\text { content }\end{array}$ \\
\hline $\begin{array}{l}\text { Yasuhiro } \\
\text { Hasegawa, } \\
\text { MD, PhD }\end{array}$ & $\begin{array}{l}\text { St. Marianna University } \\
\text { School of Medicine, } \\
\text { Kawasaki, Japan }\end{array}$ & $\begin{array}{l}\text { Execution of ATACH2, revised } \\
\text { the manuscript for intellectual } \\
\text { content }\end{array}$ \\
\hline $\begin{array}{l}\text { Yoshiaki } \\
\text { Shiokawa, } \\
\text { MD, PhD }\end{array}$ & $\begin{array}{l}\text { Kyorin University School } \\
\text { of Medicine, Mitaka, } \\
\text { Japan }\end{array}$ & $\begin{array}{l}\text { Execution of ATACH2, revised } \\
\text { the manuscript for intellectual } \\
\text { content }\end{array}$ \\
\hline $\begin{array}{l}\text { Toru } \\
\text { Iwama, MD, } \\
\text { PhD }\end{array}$ & $\begin{array}{l}\text { Gifu University } \\
\text { Graduate School of } \\
\text { Medicine, Japan }\end{array}$ & $\begin{array}{l}\text { Execution of ATACH2, revised } \\
\text { the manuscript for intellectual } \\
\text { content }\end{array}$ \\
\hline $\begin{array}{l}\text { Kenji } \\
\text { Kamiyama, } \\
\text { MD, PhD }\end{array}$ & $\begin{array}{l}\text { Nakamura Memorial } \\
\text { Hospital, Sapporo, } \\
\text { Japan }\end{array}$ & $\begin{array}{l}\text { Execution of ATACH2, revised } \\
\text { the manuscript for intellectual } \\
\text { content }\end{array}$ \\
\hline $\begin{array}{l}\text { Haruhiko } \\
\text { Hoshino, } \\
\text { MD, PhD }\end{array}$ & $\begin{array}{l}\text { Tokyo Saiseikai Central } \\
\text { Hospital, Japan }\end{array}$ & $\begin{array}{l}\text { Execution of ATACH2, revised } \\
\text { the manuscript for intellectual } \\
\text { content }\end{array}$ \\
\hline $\begin{array}{l}\text { Thorsten } \\
\text { Steiner, MD, } \\
\text { PhD }\end{array}$ & $\begin{array}{l}\text { Klinikum Frankfurt } \\
\text { Höchst, Germany }\end{array}$ & $\begin{array}{l}\text { Execution of ATACH2 (major } \\
\text { role in the acquisition of data), } \\
\text { revised the manuscript for } \\
\text { intellectual content }\end{array}$ \\
\hline $\begin{array}{l}\text { Byung-Woo } \\
\text { Yoon, MD, } \\
\text { PhD }\end{array}$ & $\begin{array}{l}\text { Seoul National } \\
\text { University Hospital, } \\
\text { South Korea }\end{array}$ & $\begin{array}{l}\text { Execution of ATACH2 (major } \\
\text { role in the acquisition of data), } \\
\text { revised the manuscript for } \\
\text { intellectual content }\end{array}$ \\
\hline $\begin{array}{l}\text { Yongjun } \\
\text { Wang, MD, } \\
\text { PhD }\end{array}$ & $\begin{array}{l}\text { Beijing Tiantan Hospital, } \\
\text { China }\end{array}$ & $\begin{array}{l}\text { Execution of ATACH2 (major } \\
\text { role in the acquisition of data), } \\
\text { revised the manuscript for } \\
\text { intellectual content }\end{array}$ \\
\hline $\begin{array}{l}\text { Chung Y. } \\
\text { Hsu, MD, } \\
\text { PhD }\end{array}$ & $\begin{array}{l}\text { China Medical } \\
\text { University, Taichung, } \\
\text { Taiwan }\end{array}$ & $\begin{array}{l}\text { Execution of ATACH2 (major } \\
\text { role in the acquisition of data), } \\
\text { revised the manuscript for } \\
\text { intellectual content }\end{array}$ \\
\hline $\begin{array}{l}\text { Adnan I. } \\
\text { Qureshi, } \\
\text { MD, PhD }\end{array}$ & $\begin{array}{l}\text { University of Minnesota, } \\
\text { Minneapolis }\end{array}$ & $\begin{array}{l}\text { Execution of ATACH2, conception } \\
\text { and design of ATACH2, revised } \\
\text { the manuscript for intellectual } \\
\text { content }\end{array}$ \\
\hline
\end{tabular}

Appendix 2 ATACH-2 Trial Investigators

\begin{tabular}{llll}
\hline Name & Location & Role & Contribution \\
\hline $\begin{array}{l}\text { Kazuyuki } \\
\text { Nagatsuka, } \\
\text { MD }\end{array}$ & $\begin{array}{l}\text { National Cerebral and } \\
\text { Cardiovascular Center, } \\
\text { Suita, Japan }\end{array}$ & $\begin{array}{l}\text { Site } \\
\text { investigator }\end{array}$ & $\begin{array}{l}\text { Acquisition of } \\
\text { data (79 } \\
\text { participants) }\end{array}$ \\
\hline $\begin{array}{l}\text { Yongjun } \\
\text { Wang, MD }\end{array}$ & $\begin{array}{l}\text { Beijing Tiantan Hospital, } \\
\text { China }\end{array}$ & $\begin{array}{l}\text { Site } \\
\text { investigator }\end{array}$ & $\begin{array}{l}\text { Acquisition of } \\
\text { data (72 } \\
\text { participants) }\end{array}$ \\
\hline $\begin{array}{l}\text { Nobuyuki } \\
\text { Sakai, MD }\end{array}$ & $\begin{array}{l}\text { Kobe City Medical Center } \\
\text { General Hospital, Japan }\end{array}$ & $\begin{array}{l}\text { Site } \\
\text { investigator }\end{array}$ & $\begin{array}{l}\text { Acquisition of } \\
\text { data (53 } \\
\text { participants) }\end{array}$ \\
\hline
\end{tabular}

Continued 
Appendix 2 (continued)

\begin{tabular}{|c|c|c|c|}
\hline Name & Location & Role & Contribution \\
\hline $\begin{array}{l}\text { Takayuki } \\
\text { Hara, MD }\end{array}$ & $\begin{array}{l}\text { Toranomon Hospital, } \\
\text { Tokyo, Japan }\end{array}$ & $\begin{array}{l}\text { Site } \\
\text { investigator }\end{array}$ & $\begin{array}{l}\text { Acquisition of } \\
\text { data (38 } \\
\text { participants) }\end{array}$ \\
\hline $\begin{array}{l}\text { Zhimin } \\
\text { Wang, MD }\end{array}$ & $\begin{array}{l}\text { The First People's } \\
\text { Hospital of Taizhou, } \\
\text { China }\end{array}$ & $\begin{array}{l}\text { Site } \\
\text { investigator }\end{array}$ & $\begin{array}{l}\text { Acquisition of } \\
\text { data ( } 37 \\
\text { participants) }\end{array}$ \\
\hline $\begin{array}{l}\text { Jiann-Shing } \\
\text { Jeng, MD }\end{array}$ & $\begin{array}{l}\text { National Taiwan } \\
\text { University Hospital, } \\
\text { Taipei }\end{array}$ & $\begin{array}{l}\text { Site } \\
\text { investigator }\end{array}$ & $\begin{array}{l}\text { Acquisition of } \\
\text { data ( } 36 \\
\text { participants) }\end{array}$ \\
\hline $\begin{array}{l}\text { Sachin } \\
\text { Agarwal, } \\
\text { MD }\end{array}$ & $\begin{array}{l}\text { Columbia University, } \\
\text { New York City, NY }\end{array}$ & $\begin{array}{l}\text { Site } \\
\text { investigator }\end{array}$ & $\begin{array}{l}\text { Acquisition of } \\
\text { data ( } 27 \\
\text { participants) }\end{array}$ \\
\hline $\begin{array}{l}\text { M. Fareed K } \\
\text { Suri, MD }\end{array}$ & St. Cloud Hospital, MN & $\begin{array}{l}\text { Site } \\
\text { investigator }\end{array}$ & $\begin{array}{l}\text { Acquisition of } \\
\text { data ( } 26 \\
\text { participants) }\end{array}$ \\
\hline $\begin{array}{l}\text { Qaisar A. } \\
\text { Shah, MD }\end{array}$ & $\begin{array}{l}\text { Abington Memorial } \\
\text { Hospital, PA }\end{array}$ & $\begin{array}{l}\text { Site } \\
\text { investigator }\end{array}$ & $\begin{array}{l}\text { Acquisition of } \\
\text { data ( } 23 \\
\text { participants) }\end{array}$ \\
\hline $\begin{array}{l}\text { Jawad F. } \\
\text { Kirmani, } \\
\text { MD }\end{array}$ & $\begin{array}{l}\text { New Jersey } \\
\text { Neuroscience Institute, } \\
\text { JFK Medical Center, } \\
\text { Edison }\end{array}$ & $\begin{array}{l}\text { Site } \\
\text { investigator }\end{array}$ & $\begin{array}{l}\text { Acquisition of } \\
\text { data (18 } \\
\text { participants) }\end{array}$ \\
\hline $\begin{array}{l}\text { Ching- } \\
\text { Huang Lin, } \\
\text { MD }\end{array}$ & $\begin{array}{l}\text { Kaohsiung Veterans } \\
\text { General Hospital, Taiwan }\end{array}$ & $\begin{array}{l}\text { Site } \\
\text { investigator }\end{array}$ & $\begin{array}{l}\text { Acquisition of } \\
\text { data ( } 16 \\
\text { participants) }\end{array}$ \\
\hline $\begin{array}{l}\text { Jose I. } \\
\text { Suarez, MD }\end{array}$ & $\begin{array}{l}\text { Baylor College of } \\
\text { Medicine, Houston, TX }\end{array}$ & $\begin{array}{l}\text { Site } \\
\text { investigator }\end{array}$ & $\begin{array}{l}\text { Acquisition of } \\
\text { data ( } 16 \\
\text { participants) }\end{array}$ \\
\hline $\begin{array}{l}\text { Pramod } \\
\text { Sethi, MD }\end{array}$ & $\begin{array}{l}\text { Guilford Neurologic } \\
\text { Associates, Greensboro, } \\
\text { NC }\end{array}$ & $\begin{array}{l}\text { Site } \\
\text { investigator }\end{array}$ & $\begin{array}{l}\text { Acquisition of } \\
\text { data (16 } \\
\text { participants) }\end{array}$ \\
\hline $\begin{array}{l}\text { Yoshiaki } \\
\text { Shiokawa, } \\
\text { MD }\end{array}$ & $\begin{array}{l}\text { Kyorin University, } \\
\text { Mitaka, Japan }\end{array}$ & $\begin{array}{l}\text { Site } \\
\text { investigator }\end{array}$ & $\begin{array}{l}\text { Acquisition of } \\
\text { data ( } 16 \\
\text { participants) }\end{array}$ \\
\hline $\begin{array}{l}\text { Yasuhiro } \\
\text { Hasegawa, } \\
\text { MD }\end{array}$ & $\begin{array}{l}\text { St. Marianna University } \\
\text { Hospital, Kawasaki, } \\
\text { Japan }\end{array}$ & $\begin{array}{l}\text { Site } \\
\text { investigator }\end{array}$ & $\begin{array}{l}\text { Acquisition of } \\
\text { data ( } 16 \\
\text { participants) }\end{array}$ \\
\hline $\begin{array}{l}\text { Chun-Lin } \\
\text { Liu, MD }\end{array}$ & $\begin{array}{l}\text { China Medical University } \\
\text { Hospital, Taichung, } \\
\text { Taiwan }\end{array}$ & $\begin{array}{l}\text { Site } \\
\text { investigator }\end{array}$ & $\begin{array}{l}\text { Acquisition of } \\
\text { data (16 } \\
\text { participants) }\end{array}$ \\
\hline $\begin{array}{l}\text { Thomas } \\
\text { Bergman, } \\
\text { MD }\end{array}$ & $\begin{array}{l}\text { Hennepin County } \\
\text { Medical Center, } \\
\text { Minneapolis, MN }\end{array}$ & $\begin{array}{l}\text { Site } \\
\text { investigator }\end{array}$ & $\begin{array}{l}\text { Acquisition of } \\
\text { data (14 } \\
\text { participants) }\end{array}$ \\
\hline $\begin{array}{l}\text { Toru } \\
\text { Iwama, MD }\end{array}$ & $\begin{array}{l}\text { Gifu University Hospital, } \\
\text { Japan }\end{array}$ & $\begin{array}{l}\text { Site } \\
\text { investigator }\end{array}$ & $\begin{array}{l}\text { Acquisition of } \\
\text { data ( } 14 \\
\text { participants) }\end{array}$ \\
\hline $\begin{array}{l}\text { Julian } \\
\text { Boesel, MD }\end{array}$ & $\begin{array}{l}\text { University Hospital } \\
\text { Heidelberg, Germany }\end{array}$ & $\begin{array}{l}\text { Site } \\
\text { investigator }\end{array}$ & $\begin{array}{l}\text { Acquisition of } \\
\text { data (14 } \\
\text { participants) }\end{array}$ \\
\hline $\begin{array}{l}\text { Kenji } \\
\text { Kamiyama, } \\
\text { MD }\end{array}$ & $\begin{array}{l}\text { Nakamura Memorial } \\
\text { Hospital, Sapporo, Japan }\end{array}$ & $\begin{array}{l}\text { Site } \\
\text { investigator }\end{array}$ & $\begin{array}{l}\text { Acquisition of } \\
\text { data (13 } \\
\text { participants) }\end{array}$ \\
\hline $\begin{array}{l}\text { Gustavo } \\
\text { Pradilla, } \\
\text { MD }\end{array}$ & $\begin{array}{l}\text { Grady Memorial } \\
\text { Hospital, Atlanta, GA }\end{array}$ & $\begin{array}{l}\text { Site } \\
\text { investigator }\end{array}$ & $\begin{array}{l}\text { Acquisition of } \\
\text { data (12 } \\
\text { participants) }\end{array}$ \\
\hline $\begin{array}{l}\text { Katherine } \\
\text { Palmieri, } \\
\text { MD }\end{array}$ & $\begin{array}{l}\text { Kansas University Medical } \\
\text { Center, Kansas City }\end{array}$ & $\begin{array}{l}\text { Site } \\
\text { investigator }\end{array}$ & $\begin{array}{l}\text { Acquisition of } \\
\text { data (12 } \\
\text { participants) }\end{array}$ \\
\hline
\end{tabular}

Appendix 2 (continued)

\begin{tabular}{llll}
\hline Name & Location & Role & Contribution \\
\hline $\begin{array}{l}\text { Chitra } \\
\text { Venkata } \\
\text { subram- } \\
\text { anian MD }\end{array}$ & Stanford University, CA & $\begin{array}{l}\text { Site } \\
\text { investigator }\end{array}$ & $\begin{array}{l}\text { Acquisition of } \\
\text { data (12 } \\
\text { participants) }\end{array}$ \\
\hline $\begin{array}{l}\text { Haruhiko } \\
\text { Hoshino, } \\
\text { MD }\end{array}$ & $\begin{array}{l}\text { Tokyo Saiseikai Central } \\
\text { Hospital, Japan }\end{array}$ & $\begin{array}{l}\text { Site } \\
\text { investigator }\end{array}$ & $\begin{array}{l}\text { Acquisition of } \\
\text { data (12 } \\
\text { participants) }\end{array}$ \\
\hline $\begin{array}{l}\text { Yuhua } \\
\text { Chen, MD }\end{array}$ & $\begin{array}{l}\text { Wuhan Brain Hospital, } \\
\text { China }\end{array}$ & $\begin{array}{l}\text { Site } \\
\text { investigator }\end{array}$ & $\begin{array}{l}\text { Acquisition of } \\
\text { data (12 } \\
\text { participants) }\end{array}$ \\
\hline
\end{tabular}

\section{References}

1. GBD 2016 Stroke Collaborators.Global, regional, and national burden of stroke, 1990-2016: a systematic analysis for the Global Burden of Disease Study 2016. Lancet Neurol 2019;18:439-458.

2. Fonarow GC, Reeves MJ, Smith EE, et al. Characteristics, performance measures, and in-hospital outcomes of the first one million stroke and transient ischemic attack admissions in Get With The Guidelines-Stroke. Circ Cardiovasc Qual Outcomes 2010;3:291-302.

3. Toyoda K, Inoue M, Koga M. Small but steady steps in stroke medicine in Japan. J Am Heart Assoc 2019;8:e013306.

4. Toyoda K, Anderson CS, Mayer S, editors. New Insights in Intracerebral Hemorrhage. Basel: Karger AG, 2015.

5. Toyoda K, Koga M, Sato S. What are the next breakthroughs in the management of acute intracerebral hemorrhage? Int J Stroke 2016;11:386-388.

6. Anderson CS, Heeley E, Huang Y, et al. Rapid blood-pressure lowering in patients with acute intracerebral hemorrhage. N Engl J Med 2013;368:2355-2365.

7. Qureshi AI, Palesch YY, Barsan WG, et al. Intensive blood-pressure lowering in patients with acute cerebral hemorrhage. N Engl J Med 2016;375:1033-1043.

8. Toyoda K, Koga M, Yamamoto H, et al. Clinical outcomes depending on acute blood pressure after cerebral hemorrhage. Ann Neurol 2019;85:105-113.

9. Fukuda-Doi M, Yamamoto H, Koga M, et al. Sex differences in blood pressurelowering therapy and outcomes following intracerebral hemorrhage: results from ATACH-2. Stroke 2020;51:2282-2286.

10. Qureshi AI, Palesch YY. Antihypertensive Treatment of Acute Cerebral Hemorrhage (ATACH) II: design, methods, and rationale. Neurocrit Care 2011;15:559-576.

11. Al-Shahi Salman R, Frantzias J, Lee RJ, et al. Absolute risk and predictors of the growth of acute spontaneous intracerebral haemorrhage: a systematic review and metaanalysis of individual patient data. Lancet Neurol 2018;17:885-894.

12. Boulouis G, Morotti A, Goldstein JN, Charidimou A. Intensive blood pressure lowering in patients with acute intracerebral haemorrhage: clinical outcomes and haemorrhage expansion: systematic review and meta-analysis of randomised trials. J Neurol Neurosurg Psychiatry 2017;88:339-345.

13. Moullaali TJ, Wang X, Martin RH, et al. Blood pressure control and clinical outcomes in acute intracerebral haemorrhage: a preplanned pooled analysis of individual participant data. Lancet Neurol 2019;18:857-864.

14. Toyoda K, Koga M, Hayakawa M, Yamagami H. Acute reperfusion therapy and stroke care in Asia after successful endovascular trials. Stroke 2015;46:1474-1481.

15. Shen AY, Yao JF, Brar SS, Jorgensen MB, Chen W. Racial/ethnic differences in the risk of intracranial hemorrhage among patients with atrial fibrillation. J Am Coll Cardiol 2007;50:309-315.

16. van Asch CJ, Luitse MJ, Rinkel GJ, van der Tweel I, Algra A, Klijn CJ. Incidence, case fatality, and functional outcome of intracerebral haemorrhage over time, according to age, sex, and ethnic origin: a systematic review and meta-analysis. Lancet Neurol 2010; 9:167-176.

17. Mozaffarian D, Fahimi S, Singh GM, et al. Global sodium consumption and death from cardiovascular causes. N Engl J Med 2014;371:624-634.

18. Shen AY, Chen W, Yao JF, Brar SS, Wang X, Go AS. Effect of race/ethnicity on the efficacy of warfarin: potential implications for prevention of stroke in patients with atrial fibrillation. CNS Drugs 2008;22:815-825.

19. Krishnan K, Beishon L, Berge E, et al. Relationship between race and outcome in Asian, Black, and Caucasian patients with spontaneous intracerebral hemorrhage: data from the Virtual International Stroke Trials Archive and Efficacy of Nitric Oxide in Stroke trial. Int J Stroke 2018;13:362-373.

20. Brott $\mathrm{T}$, Broderick J, Kothari R, et al. Early hemorrhage growth in patients with intracerebral hemorrhage. Stroke 1997;28:1-5.

21. Davis SM, Broderick J, Hennerici M, et al. Hematoma growth is a determinant of mortality and poor outcome after intracerebral hemorrhage. Neurology 2006;66: $1175-1181$.

22. Kazui S, Naritomi H, Yamamoto H, Sawada T, Yamaguchi T. Enlargement of spontaneous intracerebral hemorrhage: incidence and time course. Stroke 1996;27:1783-1787.

23. Carcel C, Wang X, Sato S, et al. Degree and timing of intensive blood pressure lowering on hematoma growth in intracerebral hemorrhage: intensive blood 
pressure reduction in Acute Cerebral Hemorrhage Trial-2 results. Stroke 2016;47: 1651-1653.

24. Yamaguchi Y, Koga M, Sato S, et al. Early achievement of blood pressure lowering and hematoma growth in acute intracerebral hemorrhage: Stroke Acute Management With Urgent Risk-Factor Assessment and Improvement-Intracerebral Hemorrhage Study. Cerebrovasc Dis 2018;46:118-124.
25. Leasure AC, Qureshi AI, Murthy SB, et al. Association of intensive blood pressure reduction with risk of hematoma expansion in patients with deep intracerebral hemorrhage. JAMA Neurol 2019;76:949-955.

26. Burgess LG, Goyal N, Jones GM, et al. Evaluation of acute kidney injury and mortality after intensive blood pressure control in patients with intracerebral hemorrhage. J Am Heart Assoc 2018;7:1-11. 


\section{Neurology}

\section{Regional Differences in the Response to Acute Blood Pressure Lowering After Cerebral Hemorrhage}

Kazunori Toyoda, Yuko Y. Palesch, Masatoshi Koga, et al.

Neurology 2021;96;e740-e751 Published Online before print November 20, 2020

DOI 10.1212/WNL.0000000000011229

This information is current as of November 20, 2020

\section{Updated Information \&} Services

References

Subspecialty Collections

Permissions \& Licensing

Reprints including high resolution figures, can be found at: http://n.neurology.org/content/96/5/e740.full

This article cites 25 articles, 8 of which you can access for free at: http://n.neurology.org/content/96/5/e740.full\#ref-list-1

This article, along with others on similar topics, appears in the following collection(s):

Clinical trials Randomized controlled (CONSORT agreement)

http://n.neurology.org/cgi/collection/clinical_trials_randomized_contro lled_consort_agreement

Intracerebral hemorrhage

http://n.neurology.org/cgi/collection/intracerebral_hemorrhage

Information about reproducing this article in parts (figures,tables) or in its entirety can be found online at:

http://www.neurology.org/about/about_the_journal\#permissions

Information about ordering reprints can be found online:

http://n.neurology.org/subscribers/advertise

Neurology ${ }^{\circledR}$ is the official journal of the American Academy of Neurology. Published continuously since 1951 , it is now a weekly with 48 issues per year. Copyright Copyright (C) 2020 The Author(s). Published by Wolters Kluwer Health, Inc. on behalf of the American Academy of Neurology.. All rights reserved. Print ISSN: 0028-3878. Online ISSN: 1526-632X.

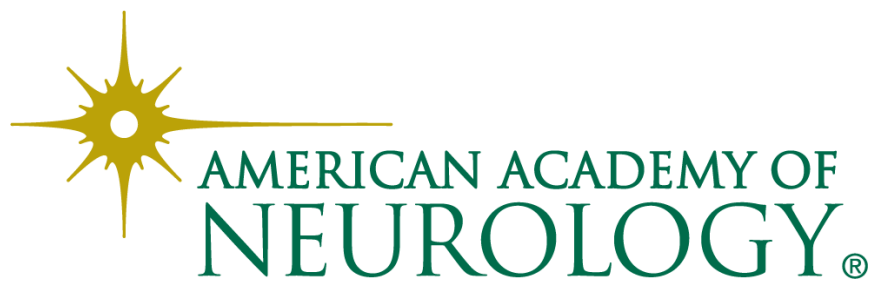

